\title{
Neo-Poulantzian Perspectives in IR and the Current Crisis
}

\author{
Ougaard, Morten
}

Document Version

Final published version

Publication date:

2013

\section{License \\ CC BY-NC-ND}

Citation for published version (APA):

Ougaard, M. (2013). Neo-Poulantzian Perspectives in IR and the Current Crisis. Copenhagen Business School [wp].

Link to publication in CBS Research Portal

\section{General rights}

Copyright and moral rights for the publications made accessible in the public portal are retained by the authors and/or other copyright owners and it is a condition of accessing publications that users recognise and abide by the legal requirements associated with these rights.

\section{Take down policy}

If you believe that this document breaches copyright please contact us (research.lib@cbs.dk) providing details, and we will remove access to the work immediately and investigate your claim. 


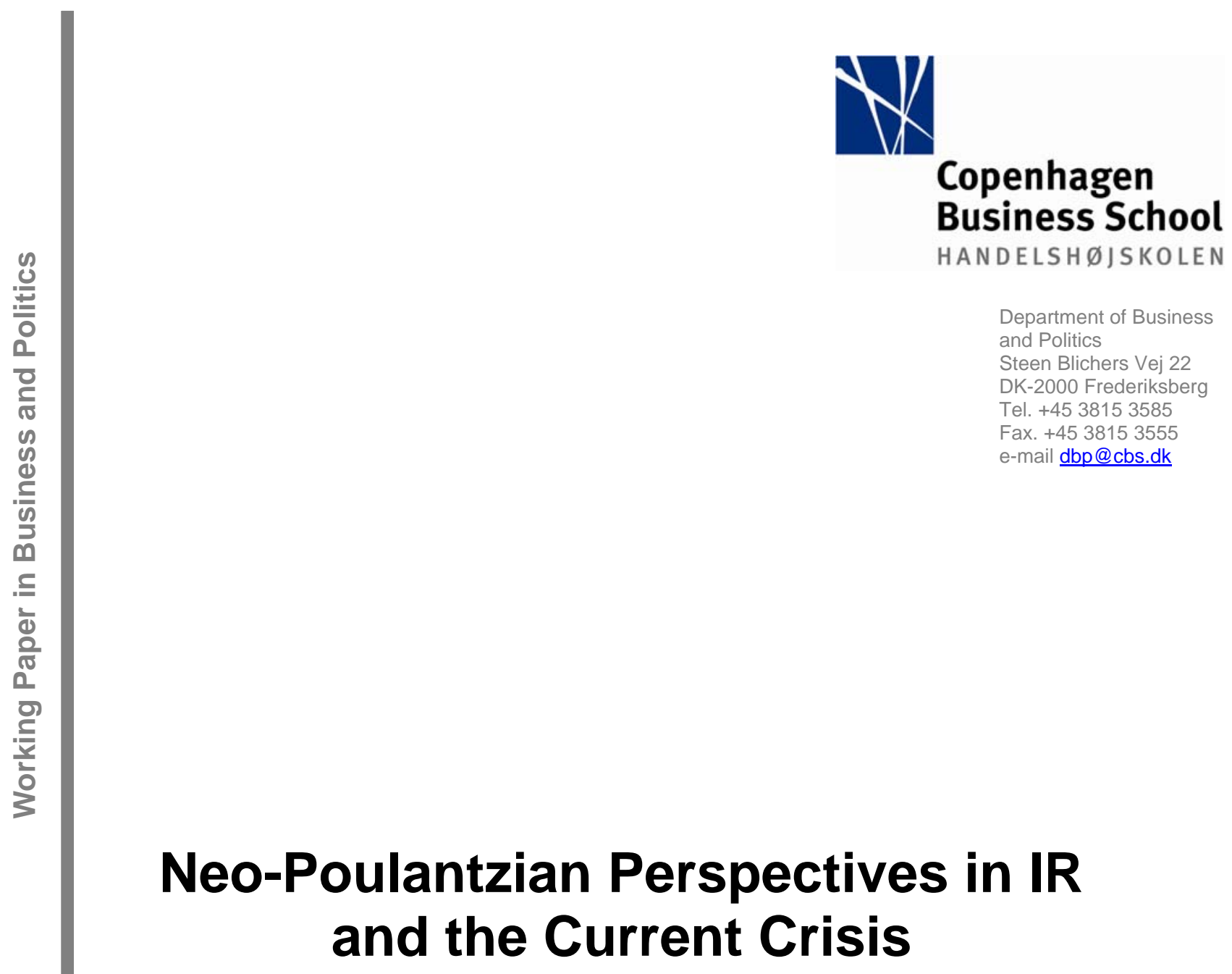

Morten Ougaard 
Working paper no 78, 2013

Editor: Lita Lundquist

Department of Business and Politics

Copenhagen Business School

Steen Blichers Vej 22

DK-2000 Frederiksberg

Phone: +45 38153585

E-mail: dbp@dbp.cbs

www.cbs.dk/dbp

ISBN: 87-91690-84-6 


\section{Neo-Poulantzian Perspectives in IR and the Current Crisis ${ }^{1}$}

\section{February 2013}

Morten Ougaard, Department of Business and Politics, CBS, Mo.dbp@cbs.dk

\section{Introduction}

This paper is about Poulantzas, historical materialism, international relations, and the current crisis. My purpose is to discuss how some Poulantzian theoretical contributions can be applied to the study of subject matters that are the focus of academic fields such as International Relations (IR), International Political Economy (IPE), International Politics, World Politics and others. I deliberately abstain from singling out any of these disciplines or fields or labels and from trying to define them precisely, because one of my arguments is that historical materialism $(\mathrm{HM})$ is a research program ${ }^{2}$ that contains its own theoretical definition of the object under study. This object, with inspiration from Poulantzas' notion of the imperialist chain and his general theory of society, I will define as the global social formation or for short, world society.

My main reason for using the label neo-Poulantzian is that the bulk of my argument concerns the transferal to the global level of concepts that Poulantzas developed for the analysis of nation states (or social formations in his terminology). He also had some highly suggestive comments on the global realm but, as we shall see, they remained largely metaphorical and under-theorized, especially when compared to the great effort he otherwise put into developing, defining, discussing, sharpening, and justifying his key concepts. Elsewhere I have argued why this move, to apply theory developed for the analysis of domestic society to international and global affairs, is made increasingly relevant by the qualitative step upwards in societal internationalization. I also showed that a growing number of scholars from a variety of theoretical camps are taking similar steps. ${ }^{3}$

\footnotetext{
${ }^{1}$ Previous versions of this paper were presented at a department seminar at DBP, CBS, November 2012, and at the workshop "Mit Poulantzas arbeiten", Institut für Politikwissenschaft, Universität Wien, December 13-15 2012. I am grateful for comments from my colleagues at DBP, especially Edward Ashbee, Iver Kjar, Juan Sturrico and Hubert Buch Hansen. At the seminar in Vienna I benefited from many discussions, but particularly from interventions from Ulrich Brand, Bob Jessop, and Andreas Bieler.

${ }^{2}$ With inspiration from Imre Lakatos (1978) I understand a research program as a set of interconnected concepts and presuppositions that define the object for inquiry and the questions for research, along with some causal hypotheses and explanatory principles, all of which can operate at different levels of abstraction and be subject to further specification and modification and thus is, essentially, an open-ended agenda for research. ${ }^{3}$ Ougaard 2002.
} 
Thus my contention is that Poulantzas' works has several potentially fruitful contributions to HM's research program on societal processes and institutions at a global or quasi-global scale. First I will discuss selected elements in Poulantzas’ general theory of society, in particular his approach to the structure-agency question which has been much discussed in recent IR scholarship. Next I will look at some more specified and concrete concepts that I find particular relevant to the analysis of world society, and finally I will sketch an analysis of the current international situation ${ }^{4}$, using these concepts. Before engaging with these questions, however, some further preliminary comments are required.

Firstly, there are two themes that I will not discuss in spite of their importance: Poulantzas' Althusser inspired epistemology, which I consider to be close to Bhaskar's critical realism ${ }^{5}$ and Colin Wight's scientific realism ${ }^{6}$, and Poulantzas' use of and contributions to Marxist economic theory, which was an important dimension of his work.

Secondly, because of the genesis of the present paper, I find it relevant to begin with a short indication of my reading of Poulantzas. Having read him extensively many years ago, and having used some of his contributions in my own work on international relations and international politics, ${ }^{7}$ I was more recently commissioned to write a small Danish volume on Poulantzas for a book series on Classics in Political Science. ${ }^{8}$ This prompted me to reread his main works, i.e. the five books ${ }^{9}$, which, given my time constraints, prevented me from re-engaging with the secondary literature and debates ${ }^{10}$ in any systematic or thorough fashion. The present paper, in consequence, is largely based on my reading of Poulantzas which, of course, is open to debate. What I find important to stress is that although his work underwent considerable development over the years, there is also a remarkable continuity and stability in many core themes. Therefore I devote section 2 to some general indications of my reading of Pou-

\footnotetext{
${ }^{4}$ In this paper I use the words international and global rather indiscriminately. This is simply a question of variation. I use both these words to refer to phenomena of a larger scale than the nation state.

${ }^{5}$ Bhaskar 1998.

6 , Wight 2006.

${ }^{7}$ Ougaard 1990,Ougaard 2004.

${ }^{8}$ Ougaard 2011a.

${ }^{9}$ Political Power and Social Classes 1973 (PPSC in the following), Fascism and Dictatorship 1974 (FD), Classes in Contemporary Capitalism 1978(CCC), The Crisis of the Dictatorships 1975 (CD) and State, Power, Socialism 1980 (SPS). Full references in the bibliography including year of publication of French originals.

${ }^{10}$ E.g. Jessop 1982, Jessop 1985, Martin 2008, Hall 1980, Bretthauer et.al. 2006, Carnoy \& Castells 2001.
} 
lantzas. In section 3 I discuss structure, agency and the concept of the conjuncture, followed by a discussion of the imperialist chain in section 4 . Section 5 focusses on elements in Poulantzas' state theory under the heading of the partial globalization of statehood, where after section 6 discuss the core notions of power bloc, hegemony, and crisis. Finally, section 7 sketches an analysis of the present conjuncture as a crisis of hegemony.

\section{Change, development, and continuity in Poulantzas}

Poulantzas remained committed to the socialist left and the workers' movement throughout his career, but there is a clear change in his political stance over the years. His early works were written within a revolutionary Leninist problematique, emphasizing the need for a radical break with capitalism and supporting the theory of the dictatorship of the proletariat. ${ }^{11}$ Ten years later, in SPS, he criticizes and abandons the notion of the dictatorship of the proletariat ${ }^{12}$ and makes a firm commitment to democracy: "Socialism will be democratic or it will not be at all."13 Now he addresses a presumptive critique for having "given in to traditional reformism." 14

A related change has to do more with tone and rhetoric than with substance. In the early works he frequently referred to a kind of genuine Marxism on whose behalf he spoke. Examples abound, in particular in PPSC: "we must return to the scientific Marxist conception of the state” ${ }^{\prime 15}$, "there is another distortion of the Marxist theory of social classes." ${ }^{16}$ When combined with his Althusser-inspired description of his method where "theoretical practice" can appear to be an impersonal and agency-void process ${ }^{17}$, such phrases can almost give the impression that Poulantzas was merely a medium through which authentic Marxism spoke with authority. Compare this to the introduction to SPS: “There can be no such thing as orthodox Marxism. [..] It is not that I claim to speak in the name of some genuine Marxism, but rather the opposite. I assume responsibility for what I write and speak only in my own name.”"18

\footnotetext{
${ }^{11}$ e.g. PPSC p. 44.

12 SPS p. 256.

${ }^{13}$ SPS p. 265.

${ }^{14}$ SPS p. 265

${ }^{15}$ PPSC p. 44

${ }^{16}$ Ibid p. 62.

${ }^{17}$ Ibid p. 18, note 6.

${ }^{18}$ SPS p. 8.
} 
A third development relates to one of the most frequent critiques of his work, that of excessive structuralism or "structural abstractionism"19. As Bruff points out, in "Anglophone circles there is a tendency to caricature Poulantzas’ work as deterministic and devoid of agency. ${ }^{20}$ This structuralism, it is argued, was abandoned in later works where political agency played a much greater role. I will indicate briefly why I find this critique off the mark. First it is obvious that the word structure and derivations from it are heavily used in PPSC, appearing on almost every page. When you write sentences as the following, you open yourself to charges of excessive structuralism and abstractionism:

“.. it is true that social classes cannot be considered as a structure in the first field designated, yet they do constitute, as a structural effect, a structure in the particular frame of reference of social relations. This frame of reference is itself structured in so far as it is circumscribed by the limits set by structures, limits which are reflected as effects of the ensemble of one field on the other."21

Sentences like this are much harder to find in the later works, and it is almost as if the concern with structural dynamics and how structures are related to other structures is abandoned. In other words, it can seem as if a structuralist project, launched in PPSC, is given up.

This, in my understanding, is not correct and Poulantzas never accepted the charge of structuralism. In my view, PPSC contains a meticulous elaboration and justification of a complex theoretical framework, which then is put to work in empirical analysis in ensuing studies. It is of primary importance in this project to address the structure-agency problem, and this is a point where I find Poulantzas’ contribution particularly useful, as I will expand upon below. Here I will just state that in my reading, the careful and detailed elaboration of the structural side of the structure-agency question, and the abstract discussions of the relations between structure and agency are done as a precondition and preparation for the much more agency focused analyses that follow. Thus the critics had misunderstood his project, as he himself explained:

"A distinction designed to demonstrate the importance of the class struggle in the very process of the definition of classes [...] was perceived as according

\footnotetext{
${ }^{19}$ Miliband 1983.

${ }^{20}$ Bruff 2012 p. 2.

${ }^{21}$ PPSC p. 68.
} 
pride of place to 'structures' that were said to be external to or outside the class struggle."22

Undoubtedly, however, the very language Poulantzas used, and what he himself called the error of theoreticism ${ }^{23}$ bear a heavy responsibility for such misunderstandings. In sum, in this regard I mainly see a change in style and terminology along with a shift in focus and emphasis within the same theoretical universe.

A similar question pertains to Poulantzas' contribution to state theory. Where PPSC was concerned with a 'regional theory' of politics and the state, emphasizing how political structures related to and were determined by economic structures and the overall structures of the mode of production, while also having relative autonomy as regional structures, the later works developed a much more agency focused understanding of the state, which was further developed by Bob Jessop under the label of a strategic-relational theory of the state ${ }^{24}$.

To explain why I see this more as a shift of focus and emphasis rather than a break from 'structuralism', a few comments on the 'theoretical universe' in which Poulantzas operated are called for. First, he continued to work within the conceptual framework of a social formation defined as a structured dynamic totality that analytically can be divided into the economic, the political, and the ideational levels, each of which has relative autonomy, and in which several modes of production co-exist and are articulated with each other. Within this theoretical universe there are several distinct but interconnected types of theory. ${ }^{25}$ They can be described and grouped in different ways, but one way is to distinguish between these three:

1) Theories of pure modes of production and especially the capitalist mode of production. These are akin to Weberian 'ideal types' and not expected to exist in their pure form in reality.

2) Structural theories and analyses of social formations, real existing societies where several modes of production are combined.

\footnotetext{
22 Poulantzas 1976, reprinted in Martin, 2008, p 292.

23 Ibid 273.

24 Jessop, 1982, 1985.

${ }^{25}$ On these levels of theory, see PPSC pp. 12-18.
} 
3) Agency focused analyses of processes of change in social formations, under the heading of conjunctures, a concept to which I will return below. ${ }^{26}$

These types are inter-related and sorting out the theoretical and conceptual connections between them is a constant concern for Poulantzas and one of the reasons why he is so difficult to read.

PPSC is mainly concerned with theory of types one and two, but has in the background an ongoing reference to type three. Later works shifts the emphasis to theory types two and three, and importantly, with type three as the defining perspective (how does agency transform society, towards fascism, towards democracy, towards authoritarian statism) - but still with an ongoing reference to theory types two and one.

Thus the regional theory of the state and the strategic-relational theory are answers to two different questions. The first question is about the place and role of politics and state in the abstract conceptual model of the capitalist mode of production and the abstract-formal model of social formations; the second question is about state and politics in the ongoing evolution and change of historically specified societies. Answering the first question is a clarification of some but not all of the conceptual tools required for addressing the second. The burden of the first question is to argue, at the level of theory of pure modes of production, that politics and the state is not outside the mode of production but inside it, as a specific region or sphere with a relative autonomy. It serves to emphasize that the relative separation of economy and politics, specific to capitalism, is inherent in the concept of the capitalist mode of production. The burden of the second question is to clarify the role political institutions play in the ongoing struggles between social forces in society.

Another line of development in the oeuvre consists in the adding of new topics - theoretical as well as empirical. The conceptual framework developed in PPSC was applied to Nazism and Fascism, to the crisis of southern European dictatorships, and to contemporary issues in Europe. In these studies, he both broadened and deepened his theoretical investigations - into the internationalization of capital, class theory, in particular what he labeled the "new petty bourgeoisie”, economic state interventions, democratic regimes and political parties, nations, territory and language, and more. He also engaged in debates with new opponents on the

\footnotetext{
${ }^{26}$ Note that within each of these types, theory can operate at different levels of abstraction. Thus in my understanding the distinction between these types of theory cuts across the differentiation between levels of abstraction.
} 
French intellectual scene, where in particular Foucault and Deleuze were subjected to extensive critique.

My point is that these changes - political perspective, attitude to the possibility of an 'authentic' or orthodox Marxism, inclusion of new themes - are largely external to the core of his theoretical contributions, and that the substantive developments rather represent a shift in emphasis within the same theoretical universe along with an ongoing effort to refine and improve the theoretical concepts and perspectives. Before engaging substantively with the stable theoretical core of his contributions, I find it necessary also to address two weaknesses in his work.

One serious problem must be acknowledged and addressed. I am referring to what the historian Jane Caplan diagnosed as "a pervasive deficiency of method ... an assumption, nowhere queried in the book, that at any given moment all the empirical knowledge required for the full expression of a theorized problem does, in fact, exist”27. This is a strong criticism, but it is not unwarranted. Poulantzas habitually references the information on which he supports the conclusions to his empirical analyses, and it is evident that he in many cases has cast the net wide and digested a vast amount of data. But he rarely states explicitly how and why he has chosen the empirical indicators in question, and he rarely discusses whether the data is good enough. It seems that conclusions often are based on an impressionistic reading of available evidence.

Obviously one should not emulate Poulantzas in this regard, but this deficiency does not invalidate the usefulness of his theoretical and conceptual contributions. For example, further empirical research may show that his conclusions on the relative strength of industrial and bank capital in France in the $1970 \mathrm{~s}^{28}$ were wrong or deficient, but still the novel way in which he posed the problem theoretically is convincing and worth using in other contexts. The task for scholars who will pursue this line of inquiry will then be to construct good empirical indicators, state them explicitly, and subject them to critique.

\footnotetext{
${ }^{27}$ Caplan 1997: p 97.

${ }^{28}$ CCC 133-137
} 
A different kind of weakness is that Poulantzas sometimes chose an unnecessarily polemical tone against scholars with whom he disagreed. The famous debate with Miliband was tough, although both sides tried to maintain a civil tone. But Poulantzas could also write sentences like this: “theoretical research has been widely distorted because of the errors of Trotsky's analysis and in particular because of the ideological rubbish churned out by his successors.”29 This is not a good approach to intellectual debate by a scholar whose political writings emphasize the importance of building alliances.

Aside from the risk of provoking unnecessary animosity, this tendency may also, along with the revolutionary language of the early works, the tendency to speak on behalf of genuine scientific Marxism, and the "structural abstractionism”, have tended to overshadow both his real contributions, to which I return in the next sections, and the genuine intellectual openness that also marks his works. He could be a tough critic, but he also often appreciated contributions from other thinkers, also from outside of historical materialism. Thus he acknowledged the contributions of e.g. Max Weber, Duverger, and several contemporary American and British political scientists. The decisive question for him was whether they were serious, and concerning this, "their Marxist or non-Marxist character does not in any way provide a relevant criterion of their seriousness or their lack of seriousness." ${ }^{30}$ This general attitude, in contrast to his method in empirical research, is worth emulation.

After these general comments on change and continuity in Poulantzas, I now move on to some of the stable and enduring themes in his contribution. First the important issue of structure and agency and the related concept of the conjuncture.

\section{Structure, agency, and conjuncture}

One of the difficulties in understanding Poulantzas is that he keeps insisting on an approach to structure and agency that is one or two steps more complicated than many other answers. ${ }^{31}$ In my reading, the core message can be summarized in two principles.

\footnotetext{
${ }^{29}$ PPSC p. 325.

30 PPSC p.19.

${ }^{31}$ Colin Wight (2006) is an exception to this and his approach has much in common with Poulantzas'.
} 
The first principle is that in contrast to many caricatures of Marxism, the distinction between structure and agency is not identical to the distinction between the economy on one hand and politics and ideas on the other. The conflation of these two distinctions - the economy is structure, politics and ideas are agency - is very common, but it is one that Poulantzas clearly rejects. The notion of structure relates to all three levels, and so does agency. The ideational level is also structured - by dominant modes of thought, ways of thinking about society, and so on. Agency, or practice, is shaped by structure at all levels; by the effects of the totality of structures on practices. ${ }^{32}$ Thus economic structures alone can never explain agency; all three relatively autonomous levels have real consequences for the practices of social actors; and there is agency at all levels, economic, political, and ideational.

But this is only the first specification made by Poulantzas. The second is perhaps even more important, and is perhaps also the more difficult one to understand, given the highly abstract way in which he formulated it. Stuart Hall saw this as a problem that appeared in PPSC and remained "a tension that continued to haunt his later work", namely that "there is a doubleframework to every question - each element appearing twice, once as the 'effect of the structure', once as 'the effect of a practice”33.

In my reading this is not a tension in Poulantzas, but rather a very useful contribution to the structure-agency debate. To explain why, rather than trying to paraphrase Poulantzas at his level of abstraction, I will introduce a football analogy. Analogies are always risky and can be overdrawn, but still, for the sake of argument let us say that the material structure that exist before and during a match and constrains and enables the play consists of the formal rules, plus the materiality of the field, plus also the strength, skill, and fitness of the players of the two teams and their stock of rehearsed maneuvers and tactics and their chosen strategy for this particular match.

Within this structure, individual players have options and make choices in pursuit of victory. But the choices cannot be understood only as exercises of free will within the underlying structural framework. When a player makes a move, it is based on a reading of the current situation on the field: where are the teammates positioned, where are the opponents, who are

\footnotetext{
${ }^{32}$ PPSC pp. $64 \mathrm{ff}$.

${ }^{33}$ Hall 2000 p. viii-ix.
} 
moving in what direction, where is the weak point in the opponent's defense, how can I create an opening for my team? When an opponent makes a bold move, you must make an adequate countermove. Your actions are not only determined - constrained and enabled - by the underlying structure, they are also determined by the actions of your opponents and teammates in this particular match. The successful player is one who can read the situation correctly and act accordingly. The game is still constrained by the underlying structure, but the actions and choices made by players can only be understood on the basis of the current state of the play which they themselves have created in their interactions with the opponent. Thus their actions are doubly determined, by the underlying structure, and by the pattern created by the totality of the previous actions of the players on the field in this particular match. Having recognized this theoretically is not a 'haunting tension' but rather a result of being serious about both structure and agency and the nature of their relationship.

The concept of the conjuncture is used to designate the current state of the play, the specific situation that has evolved and is evolving as the result of the actions of all players on the field. ${ }^{34}$ I will stop using the analogy here because the underlying structure in society cannot be compared to the rules and infrastructure of football. Society is what it is - the sum total of the practices of people. Structure and conjuncture do not exist as two separate realms of reality; structures only exist in and through the practices on which they have effects. But analytically, Poulantzas suggests, is it possible and indeed necessary to distinguish between two different planes of analysis - that of structure and that of conjuncture. Thus, in class theory, he distinguishes between structural class determination, the precisely discernible position in the social division of labor, and the class position in the conjuncture. The first has effects on the second, but the second is also shaped by the ideational, political, and economic struggles in society. Poulantzas always had an analysis of structural developments in the background of his empirical studies, and in certain cases he engaged deeply in structural analysis, but his main focus in the later works was on the movement of classes and social forces in historically specific conjunctures.

\footnotetext{
${ }^{34}$ On the concept of conjuncture in historical materialism, see also Koivisto and Lahtinen 2012.
} 


\section{Comparative and international political economy: The Imperialist Chain}

Whereas the international context was largely absent from PPSC, it was given a central place in the following three books that all analyzed specific societies at a specific stage of development - Fascism and Nazism in Germany and Italy, classes and states in the Europe of the 1970s, and the crises of the Southern European dictatorships in the mid-1970s. All three focused on internal political processes in the countries concerned, but all three situated the analysis in a consideration of the countries' position in the international context.

The central concept used by Poulantzas to designate this international context was the imperialist chain, taken from Lenin's analysis of imperialism. Poulantzas repeatedly underscores the importance of this concept as a significant theoretical breakthrough that captures an important change in the real world. It cannot be doubted that he finds the concept very important, but at the same time, in his texts it remains under-theorized and largely kept at the level of metaphor - and a rather mechanical metaphor at that. This is in striking contrast to the effort he normally put into the abstract theoretical elaboration of his key concepts. Still, it is possible to draw out some theoretical implications from Poulantzas' discussion of the imperialist chain, based on the reasons he gave for the importance of the concept.

There are three interconnected elements in this. Firstly there has been a qualitative change in the interdependence of societies; they no longer can be seen as separate and independent entities that only stand in an external relationship to each other. The internal can no longer be separated from the external; the internal of one link is profoundly marked by the chain as a whole and the link's position within it: "each link of this chain reflects the chain as a whole in the specificity of its own social formation.”35

Secondly, a constitutive feature is the uneven development of the links and the existence of weak and strong links in the chain. This, he points out, should not be read as if all countries were moving in the same direction but at different speeds; the point is rather to emphasize that there are interconnections and mutual impacts so that one country's strength can be another country’s weakness.

\footnotetext{
${ }^{35}$ cCC p. 42.
} 
Thus the chain metaphor in Poulantzas brings together the two elements of interconnectedness and uneven development; and this clearly resembles and has much in common with the notion of combined and uneven development, going back to Trotsky, that has been advanced and developed in several recent contributions to HM studies of international relations. ${ }^{36}$ There are differences, however, which for lack of space cannot be discussed in this paper. I will just note that Poulantzas stresses that this is not a combination of preexisting, separate elements, (and here the chain metaphor actually is misleading), because the internal of each element is profoundly shaped and marked by the totality: "each link of this chain reflects the chain as a whole in the specificity of its own social formation,"37 and that "the site where CPM is reproduced in the imperialist stage is the imperialist chain and its links.”38 The latter point implies that the development of the chain is not derived from the logic of the capitalist mode of production, but rather that the CPM is shaped historically by the class struggle in the chain.

Thirdly, but of no less importance, Poulantzas stresses that this new situation is not only of an economic nature. The chain is an entire social system with economic, political and ideological aspects; imperialism is "a phenomenon with economic, political and ideational implications [...] "it is about the internationalization of social relations." "39 "In discussing the weakest link, Lenin discovered the imperialist chain and broke once and for all with economism.”40

What are the implications of this for HM's research program? There are important methodological and ontological consequences. Any society is now part of a larger systemic context that has profound implications for the internal dynamics of that society. The domestic affairs of a single country cannot be understood without taking the country’s international position into account. But at the same time does the ‘chain’ only consist of links, the systemic context consist of the totality of social relations within and between individual social formations.

Thus one cannot understand the systemic context without taking the domestic affairs of individual countries into account. In terms of methodology, then, one must in empirical analyses of societal development always consider both internal and external aspects; and in terms of ontology the implication is a refusal to accept the distinction between 'national' and 'interna-

\footnotetext{
${ }^{36}$ See Morton 2007 and Ashman's contribution as well as the exchange between Callinicos and Rosenberg in Anievas (ed.) 2010.

${ }^{37}$ CCC p. 42.

${ }^{38}$ CCC p. 49

${ }^{39}$ FD p. 22

${ }^{40}$ FD p. 23.
} 
tional' as being ontologically constitutive. Thus it implies a rejection of notions of "the international” as an ontologically separate realm.

Secondly, the social reality pointed to by the chain metaphor is a societal totality with economic, political and ideational aspects; it is a world order or a social formation writ large, in other words world society or the global social formation. ${ }^{41}$ I prefer the term global social formation for several reasons, among them to signal the anchoring of this totality perspective in the general theory of HM with its emphasis on the relative autonomy of politics, economy and ideology and the combined co-existence of different modes of production.

In other words, I suggest that HM's research program in the fields of IR and IP and IPE is a program for theoretical and empirical research on the global social formation understood in this way. In the following sections I will discuss how this program can further benefit from several of Poulantzas’ more specific theoretical contributions.

\section{The partial globalization of statehood}

The first of these contributions is found in Poulantzas' state theory, a central part of his work. My argument is, that although Poulantzas' mainly focused on nation states (the reference to the international context notwithstanding), his thinking on the state is highly relevant for the analysis of international and global political phenomena, as also suggested by Brand, Görg \& Wissen $^{42}$. In other words, Poulantzian state theory is relevant to questions analyzed in contemporary social science under headings like international organizations, international regimes, and global governance and in debates about the transnational state ${ }^{43}$ or the global state. $^{44}$

In Poulantzas, the abstract concept of the state covers three aspects: the state apparatuses, i.e. the material organizations or institutions of the state, the state functions, the tasks the state performs in relation to society, and state power, a social relationship that refers to relations between classes. All three aspects, I suggest, are applicable to the global level in an age where

\footnotetext{
${ }^{41}$ Ougaard 1990.

${ }^{42}$ Brand, Görg, Wissen 2011. See also Demirovic 2011.

${ }^{43}$ Cox 1987 pp 253 ff., Robinson 2002, Rupert 2003.

${ }^{44}$ Shaw 2000.
} 
also political institutions and processes are being globalized. International organizations, transnational governance networks, the proliferation of international regimes and the activities going on within them and involving the states of national societies, represent an internationalization and globalization of these aspects of 'statehood'. Thus we have international state apparatuses that undertake internationalized state functions and embody and reflect global relations of power ${ }^{45}$. I find it unwarranted - as does most other contributors to this debate - to designate this as a global state, but I find it justified and useful to identify this as a partial and uneven globalization of the three aspects of state-hood. ${ }^{46}$

I'll get back to relations of power in a later section. On the internationalized and quasi-global state apparatuses I note that Poulantzas’ observations in later works of the state as a strategic terrain, and not a monolithic bloc, is particularly pertinent. Much contestation, and not only between governments of nation states goes on here, as evidenced for instance by studies led by Jan Aart Scholte of civil society engagement with global institutions. ${ }^{47}$ Here, however, I will focus on the partial globalization of state functions.

\section{The globalization of state functions}

My key point in this regard is that Poulantzas points to an important duality in the state's functions. Overall, for him, the defining feature of a state is that it is the factor of cohesion in a social formation, in contrast to for instance to the Weberian concept of the state, in which the legitimate monopoly on violence is the defining feature. Poulantzas accepts this as also constitutive, but only for capitalist states, ${ }^{48}$ and the more fundamental feature is that of being a social formation's factor of cohesion.

This overall or global function consists of three modalities, the economic, political, and ideological modality, also described as three categories of state interventions in society. Since the overall function is a function in relation to a class-divided society it is not neutral; it has a political character. But in addition to this there is the political modality of this function, the strictly political function, which is the state's role in relation to the political struggles in socie-

\footnotetext{
${ }^{45}$ The notion of "second-order condensations of relations of power" forwarded by Brand, Görg \& Wissen (2011) points in the same direction, but still seem to prioritize power relations at the domestic level and see global relations as derived from these.

${ }^{46}$ I developed this idea at some length in Ougaard 2004.

47 Scholte 2011.

${ }^{48}$ PPSC p.47-48, n. 17.
} 
ty. Poulantzas engages in a fairly complex argumentation about how these modalities relate to each other and to the overall function, where the strictly political function is part of the overall function which is also political but so that the political function overdetermines the overall function. These passages are not the easiest read in Poulantzas, but the core of the issue seems to be a certain duality in the state's overall function, a duality that is actually well captured by a remark by Engels which Poulantzas quotes approvingly:

"The exercise of a social function was everywhere the basis of political supremacy; and further that political supremacy has existed for any length of time only when it discharged its social function". 49

The point is that in any society that persists for some time both aspects of this duality are ingrained in the state's mode of operation. The state performs a social function in its role as the factor of cohesion in society, the overall function, while at the same time its function is to reproduce relation of power within society. Accepting this duality allows and requires research on both aspects, and this includes research that focuses on each of them separately. In other words, with HM it is both possible and indeed required to consider the globalized social function, i.e. the function to reproduce society at a global level. To emphasize this point, I label this the globalized function of societal persistence. ${ }^{50}$

In the partly and unevenly globalized state in contemporary society, the function of persistence is a function to secure the reproduction and persistence of a certain type of world society. Importantly, this is a function towards global society and not only to international or transnational capital. This marks a difference, perhaps only in emphasis, to notions of the transnational state found in writers like Robinson and Cox where global governance arrangements seems to be mainly theorized in 'capital-logic' terms, i.e. as interventions and institutional underpinnings derived from the economic requirements of capital accumulation on a world scale.

Examples of this broader notion of a partly globalized function of persistence can be found in areas such as global health policy, education policy, development policies, addressing of gen-

\footnotetext{
${ }^{49}$ Engels as quoted in PPSC $p 51$.

${ }^{50}$ I elaborated this point at some length in Ougaard 2004.
} 
der issues, and in the area of environmental sustainability. ${ }^{51}$ The perspective also pertains to the function of securing political and social order through the use of legitimate violence which is partly and unevenly globalized through a multi-centered and incoherent system made up of the UN Security Council and UN peace-keeping forces, the US -centered system of military alliances, and cooperative arrangements between the coercive forces of nation states to combat transnational crime, piracy and terrorism.

I am not claiming that these elements of a global function of persistence are fully developed or are discharged in a socially acceptable way or meet criteria of democratic legitimacy or are efficiently conducted. Some are more developed than others, and some better than others meet criteria of social justice. Like all state functions they are discharged in ways that are profoundly marked by prevailing relations of power. What I am claiming, however is that these elements are real, they do exist and are important, and they should be on the agenda for the HM research program on world society.

Finally, these are functions in relation to a global social formation composed of societies in which widely different forms of capitalism are prevalent and articulated with different precapitalist modes of production and the associated political and ideological forms. Implied in this is also the fact that these societies are formally sovereign nation states wherefore interstate politics and the military power play among states also belongs in this conceptual understanding of the world. This last point calls for elaboration.

\section{Power politics}

In recent HM scholarship it has been debated whether there is room for elements of realist theory in Marxist scholarship - realist in the current IR sense of the word. ${ }^{52}$ Callinicos for instance, taking one position in this debate while warning against a reification of the military power play among states, argued that it "is necessarily a realist moment in any Marxist analysis of international relations and conjunctures [.. it] must take into account the strategies, calculations and interactions of rival political elites in the state system”. ${ }^{53}$

\footnotetext{
${ }^{51}$ Murphy 1994 was a pioneering work in this context. In Ougaard 2004 I discussed several policy areas from this perspective. See also Deacon 1997 on 'global social policy'.

52 In particular the essays in Anievas 2010. See also Teschke 2011.

${ }^{53}$ Callinicos 2010 p. 21.
} 
In a previous publication I developed a similar conclusion, based on an extension of Poulantzian state theory to the global social formation. I concluded that "the structure of power politics is a constituent feature of the global social formation” [...], it is a specific field of practice with its own specific forms of practice, notably those of diplomacy, armaments, and war." ${ }^{\text {, In }}$ short: “The structure of power politics is a praxis-determining structure like other social structures known by historical materialism”. 55

Poulantzas did not subject the notion of power politics (or any similar notion) to the kind of in-depth theoretical clarification and development that otherwise marks his contributions. But some passages show an awareness of the problem and recognition of its importance. In the analysis of the crisis of the Southern European dictatorships in the 1970s, for instance, he writes that "The Soviet presence in the Mediterranean is a constitutive feature of the new recalibration of the correlation of forces”. ${ }^{56}$ A realist element is also discernible in his discussion of Lenin's theory of imperialism in Fascism and Dictatorship. When describing "the new index of the power of politics which marks international relations in the imperialist stage" he stresses the theoretical importance of this quote from Lenin: “The essential thing for imperialism is the rivalry of several great powers aiming for hegemony, that is territorial conquests, not so much for their own sake as to weaken the enemy and usurp his hegemony' (Lenin)". 57 This points precisely to a recognition of the importance of “relative gains” so heralded by realist theory as an important structural reason why there is an autonomous logic of power politics.

These examples of an implicit acknowledgement of a realist moment in HM are, however, not the main reason behind my conclusions quoted above. The main reason is that acceptance of a realist moment is a logical consequence of the relative autonomy of politics combined with the global function of the state and the fact that global society consists of nation states with legitimate monopolies of violence.

Foreign policy, in this view, is the external aspect of the state's global function. It is directed towards creating the best possible external conditions for reproduction of society in its histor-

\footnotetext{
${ }^{54}$ Ougaard 1990 p. 326.

${ }^{55}$ Ougaard 1990 p. 327.

${ }^{56}$ CD p. 44, my translation, emphasis in original.

${ }^{57}$ FD p. 24.
} 
ically specific form and under extant relations of power, and this includes but is not limited to conditions for international economic expansion. This function requires a capacity to impact the outside world, and military might is one - but not the only one - component in this capacity. Military might must always be seen in relation to the might of other states, and therefore the struggle for power in this sense becomes a distinct interest, derived from other interests, but with a logic of its own and with important consequence for the state. I allow myself a long quote from the English summary to my Danish 1990 book:

"In general the effects of power politics on the state are quite considerable, creating in this field a significant enhancement of the relative autonomy of the political, to the degree that this field may appear as absolutely autonomous, elevated above class interests and neutral in relation to domestic conflicts. This is the real background for the large bodies of theories that treat international politics as an autonomous sphere, dominated by nation-states pursuing national interests. But in the perspective of historical materialism it is maintained that power political interests are a mediated form of class interests and should be seen in this context, and that the drive for power in the final analysis is derived from the state's overall function as the function of cohesion and persistence in relation to a class divided social order"

Thus the argument against a reification of the realist moment is that the game of power politics always is profoundly marked by the larger societal context in which it is situated. There is a qualitative difference between power politics in an era of great power rivalry and territorial expansion; in an era of conflict, competition, and cold war between opposing social systems each armed with nuclear weapons, and in the post-cold war era, where capitalism and liberal democracy, for the first time in history, are the dominant organizing principles in world society. It is this societal contextualization that allows us to understand why the game of power politics changed profoundly with the end of the cold war. The Poulantzian perspective calls for accepting the realist moment but with a double relativization: the pursuit of military might is only one element in a broader state function of coherence and persistence, and, in the age of globalization, this overall function is partly globalized as a function in relation to the global social formation.

\footnotetext{
${ }^{58}$ Ougaard 1990 p. 327.
} 


\section{Bureaucracy and 'bureaucratism'}

Bureaucracy and bureaucratism are enduring themes in Poulantzas' works. In this as in other cases a basic conceptual apparatus and analytical perspective was laid out in the first book, later to be elaborated, nuanced and applied to specific historical circumstances. In addition to the Marxist classics he built heavily on Max Weber, considering all later contributions to be extensions and elaborations on his work. ${ }^{59}$ Poulantzas' own contribution was not so much to extend Weber's analysis further, but rather to situate it in the larger context of the HM theory of society, class, and state. For this purpose he made a distinction between bureaucratism and the bureaucracy. ${ }^{60}$ Bureaucratism he defined as the organizational form with its associated patterns of thought and practices. He did not add much to what appears in most Weber inspired definitions of bureaucracy, such as an axiomatized juridical system with abstract, general, and formal rules, regulated distribution of activities and competencies, an impersonal mode of functioning, and fixed salaries and career patterns determined by objective criteria. By the bureaucracy on the other hand, he referred to the bureaucrats, the personnel that staffs the state apparatuses. This group of people, in his terminology, constitutes a social category, a term he uses to designate groups of persons that do not belong to classes based in the economic structures of society but nevertheless share a common position in the social division of labor. ${ }^{61}$ Social categories are primarily defined by their position in the political and ideological structures of society, not by their position in the economy. The state's civil bureaucracy is one such social category, the military is another, and so is the staff of educational institutions, the clergy, and the intellectuals.

One of the elements in Poulantzas' theory that distinguishes it from crude class-reductionist varieties of historical materialism is his insistence that social categories are important in their own right and can act as social and political forces with an agency and impact of their own. Concerning the state bureaucracy, Poulantzas argues that bureaucratism provides this social category with its own specific identity and internal coherence, which facilitates its ability to be, in certain circumstances, a social force that can play its own role in political processes. ${ }^{62}$

\footnotetext{
${ }^{59}$ PPSC p. 341.

${ }^{60} \mathrm{Ibid}$.

${ }^{61}$ PPSC p. 84.

${ }^{62}$ PPSC pp 334-337.
} 
Furthermore, because the bureaucracy operates on formal and impersonal principles and is the carrier of the state's function of coherence, it tends to see itself and to appear as being the guardian of the common good in society. However, Poulantzas emphasizes that this is an appearance, the bureaucracy is not in his theory above the class struggle, partly because the function of coherence as such is not neutral, and partly because what is increasingly emphasized in his later works, especially SPS, namely that internal divisions and rivalries within the bureaucracy are derived from or amplified by struggles outside of the state.

Poulantzas recognized that the bureaucracy also has its own specific interests - salaries, working conditions, career possibilities, turf fights - and that these also can play a role. But the capacity of this social category to act as a political force in society is in his view primarily a result of its role as carrier of the state functions combined with bureaucratism as a unifying organizing form and ideology.

The relevance of these elements in Poulantzas' work in the present context is, hardly surprising, due to the existence of major international bureaucracies in contemporary world society and to the integration of national bureaucracies into transnational governance networks. In recent scholarship there has been a growing attention to international bureaucracies - the staffs of the large international organizations such as the UN system, the World Bank, the IMF, the WTO, and the OECD, often with a view to assess their independent role in global political processes, or with a view to analyze how their internal dynamics impact their performance. ${ }^{63}$ In the same way it is increasingly recognized that national bureaucracies are becoming integrated into transnational governance networks, such as those centered on the OECD but also elsewhere, in a process that has implications for how they operate at the national level. ${ }^{64}$

In a Poulantzian variety of HM, the international bureaucracies, the staffs of the international organizations, constitute an important social category, and the possibility that this category in certain contexts acts as a social and political force must be acknowledged. While recognizing that narrow self-interest and organizational dysfunctions are possible, the Poulantzian perspective puts primacy on this category's internal cohesion due to bureaucratism and its role as carrier of state functions, but always seen in the larger context of the relations of power

\footnotetext{
${ }^{63}$ Barnett and Finnmore 2004, Avant et.al. 2010, Trondal et.al. 2010.

${ }^{64}$ Cox 1987, Ougaard 2004, Ougaard 2010, Slaughter 2004, Martens \& Jakobi (eds.) 2010.
} 
among all social forces. Conversely, it is also of interest in a Poulantzian perspective to analyze the extent to which the internationalization of national bureaucracies has consequences for their internal coherence and their understanding of the state functions they are responsible for. One important question is to what extent national bureaucrats re-conceptualize the national function of coherence as an element in an international or global state function as a result of this transnationalization.

\section{Power bloc, hegemony, crisis,}

Poulantzas brought considerable sophistication to the analysis of class structure (including his observations on the social categories discussed above), but equally important are the concepts and distinctions he introduced to analyze class positions and relations of power in political practice and conjunctures. It is the latter I will focus on here, presenting them in a summary fashion and then sketching out an application to the current international situation.

Poulantzas distinguished between the dominant class or classes, the governing class, and the class in charge of the state. ${ }^{65}$ The dominant class or classes (more on this below) is the class whose basic and strategic interests are secured by the state and who is economically dominant in society. The governing or ruling class is the class or category whose political party or representatives occupy the dominant places on the political scene. The class in charge of the state is the class from which the higher ranks of the bureaucracy, the military, and so on are recruited. The same class can occupy all three roles, but they can also be occupied by different classes. Thus for example a society where industrial capitalism is dominant can be governed by a party representing large landowners, while the heights of the state apparatus is staffed by persons recruited from the petty bourgeoisie or a long line of bureaucrats or military officers.

The repeated caveat dominant class or classes above is directly linked to Poulantzas' notions of the power bloc and hegemony. These notions have similarities to the Neo-Gramscian concepts of historic bloc and hegemony, and they share an inspiration from Gramsci with them. Poulantzas, however, based on a critical engagement with Gramsci, gives his own distinct

\footnotetext{
${ }^{65}$ PPSC p. 249 f.
} 
content to the two concepts which in certain ways differs from both Gramsci and the NeoGramscian notion. ${ }^{66}$

In particular it must be stressed that Poulantzas uses the concept of hegemony in two senses: The first is the Gramscian sense in which the political interests of the dominant classes are constituted as 'the general interest' of the 'body politic', i.e. as the general interest of the people/nation. The second sense, on which I will focus in this paper, is one "not actually pointed out by Gramsci, ${ }^{67}$ and it refers to the position of leadership within the power bloc taken by a class or class fraction. More on this below.

There are two reasons to introduce the notion of the power bloc. One is that capitalism in long stretches of history co-exists with pre-capitalist modes of production in such a way that the basic and strategic interests of for instance both the landed aristocracy and the capitalist bourgeoisie are secured. In such situations, found in Europe well into the 20th century, and in other parts of the world also today, there is more than one dominant class and together they constitute the power bloc in Poulantzian terms.

The second reason is that the capitalist bourgeoisie is not a completely unified class with a homogenous set of economic interests. Poulantzas refers to Marx’s analysis of capital as being divided into the three fractions of industrial, merchant, and banking capital, which on one hand has a shared interest in the growth of the entire economy, and rely on each other in multiple ways in the conduct of their business, but who also have economic conflicts of interest that ultimately, in the Marxist analysis, is rooted in a struggle over the distribution of surplus value among them. To this Poulantzas adds that with the rise of 'monopoly capitalism' ${ }^{68}$ a

\footnotetext{
${ }^{66}$ Briefly: Neo-Gramscians and Poulantzas share the combination of two aspects in their theorizations: 1) the relations of power in society, i.e. the positions the various classes and categories have in relation to each other, and 2) the emphasis on the importance of ideas and ideologies in reproducing relations of power. The difference between Poulantzas and Neo-Gramscians lies in the first of these aspects. In Neo-Gramscianism a historic bloc is a historically specific configuration of all social forces in society, while hegemony refers to the dominant class or classes in this bloc (see Morton 2007, esp. pp. 95-97, 118-19). What neo-Gramscians label a historic bloc lacks an explicit name in Poulantzas but could be called the constellation of social forces in a historically specific social formation. Hegemony in Neo-Gramscianism often refers to the dominant side in such a social formation, i.e. what Poulantzas calls the power bloc, whereas the term hegemony in Poulantzas is strictly reserved to the leading position within the power bloc. But to repeat: both Poulantzas and neo-Gramscians include the ideational dimension.

${ }^{67}$ PPSC p. 121.

${ }^{68}$ He takes this concept from a Marxist tradition going back to Hilferding that via Lenin was canonized in communist party doctrine. In opposing this doctrine Poulantzas does much to give the concept a precise theoretical
} 
new line of conflict is created between large corporations and smaller businesses. ${ }^{69}$ But the story does not end here. The internationalization of capital introduces new potential lines of conflict within countries between national companies and affiliates of foreign ones, and competition among big companies for subsidies or favorable legislation can also be a source of political conflict ${ }^{70}$. Thus Poulantzas acknowledges the possibility of many historically contingent 'contradictions within the bourgeoisie', bringing his work in this regard close to the understanding of 'business conflict' forwarded by Richard Falkner in the context of liberal 'neo-pluralist' theory ${ }^{71}$. Still Poulantzas gives primacy to the first mentioned lines of conflict. Thus fractions, and especially two of them, namely industrial and banking capital, are of permanent importance, as is the distinction between monopoly and non-monopoly capital, although he sees the latter becoming increasingly dependent on the former.

It is to accommodate this complexity that the notion of the power bloc is introduced. The dominant side of class relations in capitalist society consists of several classes and class fractions that are united but also divided by internal contradictions and this unity-with- contradictions is denoted the power-bloc. The concept of hegemony rests on the claim that the power bloc cannot function if not one of its constituent parts has a leading role. This leader is denoted the hegemon - a usage that is in accordance with the original Greek meaning of the hegemon as the leader of an alliance of city states. Incidentally it parallels the usage in IR where it typically denotes the US position in relation to Europe and other allies. ${ }^{72}$

The concepts of power bloc and hegemony were introduced in PPSC along with others - class alliances, supporting classes, dominated classes - and they were consistently used in later works to analyze relations of power in different conjunctures. Some revisions took place and new elements and dimensions were added, but the overall framework remained remarkably constant. In my assessment, this set of inter-linked concepts, contextualized in the larger framework of the elaboration of HM as a general theory, is among Poulantzas’ most im-

\footnotetext{
content that is not based on a simplistic notion of monopoly. See the chapter "The contradictions among the bourgeoisie today", pp. 109-155 in CCC.

${ }^{69}$ Not to be confused with petty producers, family or one-person firms where the owner's own labor is dominant, in contrast to capitalist businesses where hired labor is dominant. This is a very superficial rendition of an in-depth conceptual and theoretical discussion in CCC.

${ }^{70}$ CCC p. 137.

${ }^{71}$ Falkner 2008.

${ }^{72}$ See my discussion in Ougaard 1988.
} 
portant theoretical contributions and they stand out as an original and genuine contribution to political science.

These concepts were also central in his analysis of political crises. When discussing this topic, Poulantzas made two initial clarifications. Firstly that political crises are different from economic crises and that there is no necessary link between the two - an economic crisis may or may not lead to a political crisis, and a political crisis may or may not have its roots in an economic crisis. Secondly, periods of crisis should not be seen in contrast to completely tranquil periods of stability, absence of conflict, and harmony. There is always an element of instability, contestation, conflict and change in capitalist societies, but a political crisis is a period of some length - several years - where the level of contestation is heightened, confrontations are sharper, political processes seem more volatile, contradictions are intensified, and more profound change can be possible. In his own works Poulantzas discussed the crisis that led to the Russian revolution in 1917, the crises that led to the rise of Nazism and Fascism in Germany and Italy, the 1970s crises of the southern European dictatorships that led to democracy, and the crisis of the European metropolises of the 1970's which he, at the time of writing, saw as leading to certain more authoritarian features, but not to fascism or dictatorship.

A political crisis is for Poulantzas connected with but not reducible to a 'crisis of the state' ${ }^{73}$ In my reading this can also be stated as two different aspects of the crisis, where the first is about a critical modification of the relations of power within the power bloc and between the bloc and the dominated classes, and a constituent part of this is always an ideological crisis. The second aspect is about institutional disruptions, such as a crisis in the relationship between classes or fractions and their political representatives, open conflicts between different parts of the state apparatuses, and conflicts between representative and executive organs of the state. In this paper, I will address only the first aspect.

Political crises differ considerably in terms of their possible outcomes as indicated by the examples mentioned above, but at the level of power relations they come in two main types: fundamental or 'catastrophic' crises, where the existence of the state in its current form is threatened because of the strength of the dominated classes - in other words a revolutionary situation as it occurred in Russia in 1917. The outcome of such a crisis can be a revolutionary

\footnotetext{
${ }^{73}$ Poulantzas 1979.
} 
transformation of the state, but it can also be repression and re-consolidation of the power bloc. The other generic kind is crises of hegemony, i.e. situations where the previously hegemonic class or fraction is challenged and is no longer able to fulfill the role of leading the power bloc. Although centered within the power bloc, such crises also include relations between the power bloc and the dominated classes, for instance in the form of growing difficulties in maintaining a previously established pattern of support for the hegemonic project from the popular classes. Here I bring in the concept of "hegemonic projects” which is not Poulantzas' creation, but is a very useful addition to Poulantzian state theory suggested and developed by Bob Jessop. ${ }^{74}$ The outcome can both be a reconstruction of the previous hegemony, and the replacement, through a process of intensified political struggles, of the old hegemon with another class or fraction in the power bloc.

Armed with these concepts I will now sketch an argument on the current global conjuncture, arguing that it is a crisis of hegemony that is still unfolding. I stress that it is only a sketch and more empirical research is called for. Thus it can be read as a hypothesis, but in a special sense. It is a composite hypothesis, a summary statement about a configuration of social forces, political processes and political outcomes, and therefore consisting of a set of inter-linked statements each of which requires empirical support.

\section{The current crisis of hegemony}

My argument is that we presently are in a crisis of hegemony that was triggered by the financial crisis, is still unfolding, and has an uncertain outcome that will depend on the relative strength, strategies, and capacity for political action of a variety of social forces. This current crisis - a crisis of the neo-liberal hegemonic project - is the second crisis of this nature since the Second World War and it is useful to consider it in this historical context.

The first stage in this history was marked by the compromise of 'embedded liberalism', as it became known in liberal IP theory, which combined welfare states at home with international liberalization of trade, investment and towards the end also financial transactions. In Poulantzian terms the power bloc consisted of an international alliance of national capitalist classes, led by the US, in which industrial capital was hegemonic, and which politically relied on

\footnotetext{
${ }^{74}$ Jessop 1982, esp. pp. $243 \mathrm{ff}$.
} 
support from labor and other popular forces (also known as a 'Fordist growth model”). This quasi-global (it did not include the communist countries) growth model entered a period of crisis beginning in the late 1960s. This crisis of hegemony had many components which interacted with each other in multiple ways: growing labor militancy, the Vietnam War, the youth revolt of May 1968, the civil rights movement in the US, sharpened conflicts between developed and developing countries, the oil-crisis, inflationary pressures, the break-down of the international gold-based currency system, and more. It is a sobering thought that this hegemonic crisis lasted for more or less a decade, from the crisis began to break in the late 1960s until the new neo-liberal hegemonic project had established clear political leadership under Reagan and Thatcher around 1980 and began to unfold and consolidate its political agenda. This decade of crisis was, by the way, the societal background on which Poulantzas wrote.

Throughout the crisis, the core interest of continued economic internationalization was maintained, with the result that the reconstructed power bloc that came out of the crisis increasingly was transnational in nature. It is debatable whether it constituted a unified transnational class, as it was still composed of companies firmly rooted in different societies, but economic integration had reached a level where all national sections of international capitalism in the developed world had a shared interest in the continued expansion of an open global economy. ${ }^{75}$ Thus the dominant force in the reconstructed power bloc was transnational capital. A key element in the transition to this new situation was the unilateral cancellation of the welfare compromise with organized labor. Conditions differed from country to country, but it seems safe to say that the general trend was that it was replaced by a new pattern of popular support, based on anti-statism, individualism (personal freedom as the highest value), cultural conservatism, nationalism or more or less openly expressed racism in opposition to multiculturalism, and similar themes. More precisely, this "new right” in its various national guises was a genuine popular social movement with which dominant classes aligned themselves politically. The support these new agendas gained from traditional labor was not insignificant, but the core social basis seems to have been in the petty bourgeoisie and parts of the salaried employees in both the private and public sectors who are not 'workers' in the traditional sense of the word. ${ }^{76}$

\footnotetext{
${ }^{75}$ This development led Poulantzas to declare the end of the "national bourgeoisie" and replace it with the concept of the 'internal bourgeoisie'. CCC p.72.

${ }^{76}$ Poulantzas labeled this "the new petty bourgeoisie" but this did not become widely accepted.
} 
When analyzing transnational capital, the relations between the two central fractions - industrial and banking capital - is important. Terminology can be confusing here because, in line with Marxist tradition, Poulantzas uses the term finance capital to denote the integration of banking and industrial capital. This integration may or may not take the form of crossownerships, but the important feature is that the circuits of capital in these two fractions are deeply integrated and intertwined. Industrial capital puts excess liquidity in banks on an ongoing basis, and relies on banks for both short and long-term credit, and so on. Poulantzas further notes that this process of integration can be led and dominated by either of the two fractions depending on circumstances. His terminology is not convenient today, because the 'banking' fraction of capital consists of much more than banks; many new kinds of 'financial institutions' have appeared on the scene. Therefore I will follow common usage and refer to the financial sector rather than banking as a fraction of transnational capital.

As argued persuasively by David McNally, the neo-liberal project unfolded in two stages. ${ }^{77}$ In the first stage, financial de-regulation and the creation of a range of new financial products provided a useful service to the internationalization of productive capital, allowing it for example to hedge against currency risks, interest rate differences and volatility, and thereby facilitating long-term investment within a global horizon. Thus in this first stage, industrial capital was hegemonic in the sense that policy output from transnationalized state apparatuses facilitated the expansion of transnational productive capital. The world experienced a period of robust growth, fuelled also by new technologies and the dramatically expanded supply of cheap labor following the liberalized access to China, India and other countries.

Eventually, however, in a story that now is well accounted for $^{78}$, the inventiveness and greed of the financial sector, combined with excess US liquidity because of the dollar's role as the international reserve currency, the complicity and supportive monetary and regulatory policies of governments and central banks, and the temptation for popular classes to compensate for stagnant or declining real incomes by increased levels of debt, all of this combined to elevate financial capital to the hegemonic position in the power bloc. And as we know now, it did not take long before this hegemony got into deep trouble: it took less than ten years to

\footnotetext{
${ }_{77}^{77}$ McNally 2009.

${ }^{78}$ E.g. MacNally 2009, Baker 2010, Panitch and Gindin 2010, Tsingou 2010, Duncan 2012.
} 
take the world into a gigantic financial bubble that burst and pulled the world economy into a deep and prolonged economic crisis.

When assessing the current crisis of hegemony it is, however, important to remember that the finance-industry relation is not the only dividing line in the power bloc. Transnational capital is undoubtedly the dominant social force globally (but not necessarily the governing class or the class in charge of the state in Poulantzian terms), sharing a basic and strategic interest in the continued expansion of the world economy, but it is a composite entity cut through by several lines of division and conflict.

Firstly, the global power bloc, its shared strategic interests notwithstanding, is still made up national blocs, rooted in separate social formations. Thus there are conflicts of interest between the domestic bourgeoisies of the US and Europe, within Europe, between China and the West and between the power blocs in the center and the periphery. My hypothesis, however, is that most of these, although not insignificant, are secondary in relation to the reconfiguration of the global power bloc and hegemony. The one exception to this is found in the changed position of the so-called emerging economies.

Generally, among the dependent countries in the capitalist periphery there are major and significant variations in the relative strength of domestic versus foreign capital, and in the extent and manner in which pre-capitalist dominant classes are parts of the power bloc. In the emerging capitalist economies such as India, Brazil and South Africa, the domestic bourgeoisies have considerable strength and may be considered hegemonic within their social formations. A major feature of the current conjuncture, and new compared to the previous crisis, is the increased strength with which the power blocs of these countries are pressing for a position in the global power bloc that is more accommodating to their specific interests. Somehow a new hegemonic project must reflect this modification of global power relations.

Nevertheless, the most important lines of fission in the global power bloc seem to be transnational in nature. I already pointed to the finance-industry fractioning as an important dividing line, but in addition to this the pressure of environmental problems and in particular climate change has created a significant fissure in the power bloc between "green” and "black” busi- 
nesses. ${ }^{79}$ Green businesses embrace the agenda of environmental sustainability and see growth potential, new markets, and future profits in a green economy, and are often supportive of, if not demanding, state support to facilitate the transition to such a growth model. Black businesses, on the other hand, rely on a continuation of a carbon-intensive growth model and shy away from the added costs of environmental regulation. In the latter respect they can join forces with other sections of business that for one reason or the other prefer a light regulatory touch, and among these, the financial industry is important.

Thirdly there also seems to be variation in the global business community in the willingness to adopt social responsibility as more than a window-dressing measure, and the willingness to be supportive of developmental and poverty fighting agendas, and therefore also in certain respects more accommodating towards the emerging economies. This is not a question of morals or philanthropy, but rather a question of taking a long term perspective on market expansion combined with the pressures from civil society movements, as I argued in a study of the political economy of CSR (Ougaard 2006).

What we see, then, is an as yet unresolved struggle for hegemony between on one hand an alliance of finance, black industry, and other regulation-aversive businesses seeking to reconstruct the neo-liberal project, and on the other hand a coalition of businesses, anchored in productive industry, that accept stricter financial regulation, are willing to embrace and promote a green growth model, and are willing to accommodate emerging economies to some extent (while still protecting key interests such as intellectual property rights) and engage with social responsibility, while keeping the financial bottom line as the ultimate bottom line.

The first of these projects seems to strive to continue the pattern of mobilizing support of cultural conservatism, nationalism, mono-culturalism, anti-statism, and lower taxes, and thus aligning itself with the popular "new right", whereas the second one tries to mobilize support on welfare issues, employment, environmental sustainability, economic justice, multiculturalism, gender issues, and similar values. But one should not rule of the possibility of a re-engineering of both of these projects to mobilize sufficient popular support in other ways. The need for and ability to mobilize support from subaltern social forces outside the power

\footnotetext{
${ }^{79}$ Falkner 2008, Vormedal 2011.
} 
bloc is precisely, in the Poulantzian perspective, one of the key parameters in the struggle for hegemony within the power bloc.

The actors in this unfolding drama are politicians in and out of government, interest organizations and NGOs constituted both at the domestic and international levels, executives of transnational corporations and other businesses, and voters and grassroots movements left and right. But in a Poulantzian perspective, state apparatuses and the bureaucracies that staff them also play a role. This includes international organizations and their staffs in their ongoing interactions with national bureaucracies and state apparatuses. The transnationalized state is the strategic terrain where battles over the re-construction of hegemony are being fought, and in this process, the bureaucracies participate as carriers of the dual state function of societal persistence and cohesion and reproduction of relations of power. This was also the case in the previous crisis of hegemony in which, for instance, the OECD was an active participant in the construction of the neo-liberal hegemonic project. ${ }^{80}$

Therefore it is not insignificant that the OECD has embarked on a project of "enhanced engagement” with emerging economies, and more generally has adopted an agenda 'sustainable growth" understood in the triple sense of economic, environmental, and social sustainability, and that the organization's discourse supports a more "inclusive growth” model, which, at the level of discourse is social liberal and green rather than neo-liberal and black. ${ }^{81}$ In the same manner, in spite of all disappointments, it is not insignificant that there is now a large international institutional machinery and an internationally organized body of experts in the area of climate change, providing an institutional resilience to the policy goal of limiting global warming. Also in spite of set-backs, the UN system provides institutional resilience to the Millennium Development Goals, and there seems to have been a learning process going on in the World Bank (since long) and the IMF (more recently) so that they have become less inclined to follow neo-liberal policy prescriptions dogmatically.

On the other hand, however, the outcome of current national and transnational struggles over the regulation of the financial sector is still unsettled, and the possibility of finance recouping its weakened legitimacy and ability to define the terms for its own mode of operation cannot

\footnotetext{
${ }^{80}$ Ougaard 2004 pp. $89 \mathrm{ff}$, Ougaard 2010.

${ }^{81}$ Ougaard $2011 \mathrm{~b}$.
} 
be ruled out. And furthermore, in a situation of weak growth, there is a tendency to let immediate and short term concerns override all other policy goals, which also hampers the reconstruction of hegemony.

The situation, in other words, is far from settled and the eventual re-configured hegemonic project may be rather different from what we can envision today. What I think is clear from the above sketch, however, is that a challenge to the dominance of transnational capitalism is not in the cards. But the left and other progressive forces have the possibility to impact the nature of the next hegemonic project, precisely because there is a crisis of hegemony. What is at stake in the current conjuncture is the possible transition to a more sustainable - environmentally and socially - pattern of capitalist growth. And when considering this, I find it worth remembering Poulantzas' critique of the Western communist parties in the interwar years: because they fought for what was not possible in the situation - a socialist revolution - they failed to achieve what would have been possible, namely to check fascism. ${ }^{82}$

${ }^{82}$ FD p. 142. 


\section{Bibliography}

Anievas, Alexander (ed.) (2011) Marxism and World Politics. Contesting Global Capitalism, London \& New York: Routledge.

Avant, Deborah, Martha Finnemore and Susan Sell (eds.) (2010) Who Governs the Globe? Cambridge: Cambridge University Press.

Baker, Andrew (2010) "Restraining Regulatory Capture? Anglo-America, Crisis Politics and Trajectories of Change in Global Financial Governance”, International Affairs 86 (3): 647-663.

Barnett, Michael and Martha Finnemore ( 2004) Rules for the World. International Organizations in Global Politics, Ithaca and London: Cornell University Press.

Bhaskar, Roy (1998) "The logic of scientific discovery” \& "Philosophy and scientific realism” in Critical Realism. Essential readings, edited by Margaret Archer, Roy Bhaskar, Andre Collier, Tony Lawson and Alan Norrie, London and New York: Routledge.

Brand, Ulrich, Christoph Görg \& Markus Wissen (2011) "Second-Order Condensations of Societal Power Relations: Environmental Politics and the Internationalization of the State from a NeoPoulantzian Perspective”, Antipode Vol. 43 No. 12011 pp 149-175.

Bretthauer, Gallas, Kannankulam \& Stützle (Hrsg.) (2006) Poulantzas lesen, Zur Aktualität marxistischer Staatstheorie, Hamburg: VSA-Verlag.

Bruff, Ian (2012) "The relevance of Nicos Poulantzas for contemporary debates on 'the international", International Politics (2012) 49, 177-194.

Callinicos Alex (2010) “Does capitalism need the state system?” 13-26 in Marxism and World Politics. Contesting Global Capitalism, edited by Alexander Anievas, London \& New York: Routledge.

Caplan, Jane (1977) “Theories of Fascism: Nicos Poulantzas as Historian” in History Workshop no 3, 1977, pp 83-100.

Carnoy, and Castells, Manuel (2001) Martin "Globalization, the knowledge society, and the Network State: Poulantzas at the Millennium" 1-18 in Global Networks 1,1.

Cox, Robert W. (1987) Production, Power, and World Order. Social Forces in the Making of History. New York: Columbia University Press.

Deacon, Bob (with Michelle Hulse and Paul Stubbs) (1997) Global Social Policy. International organizations and the future of welfare, London: Sage Publications

Demorivic, Alex (2010) “Materialist State Theory and the Transnationalization of the State”, 38-59 in Antipode vol. 43 No.1.

Duncan, Richard (2012) “A New Global Depression?” 5 -33 in New Left Review 77 (new series).

Falkner, Robert (2008) Business Power and Conflict in International Environmental Politics, Palgrave.

Hall, Stuart (1980) 'Nicos Poulantzas: State, Power Socialism' in New Left Review No. 119.

Hilferding, Rudolf (1910) Das Finanzkapital: Eine Studie über die jüngste Entwicklung des Kapitalismus, Wien: Verlag der Wiener Volksbuchhandlung Ignaz Brand \& Co.

Jessop, Bob (1982) The Capitalist State, Oxford: Martin Robertson.

Jessop, Bob (1985) Nicos Poulantzas. Marxist Theory and Political Strategy. Houndmills: Macmillan.

Koivisto, Juha and Mikko Lahtinen (2012) "Historial-Critical Dictionary of Marxism: Conjuncture, politico-historical” in Historical Materialism, 20, 1, 267-277.

Lakatos, Imre (1978) The methodology of scientific research programmes, Philosophical Papers Volume 1, edited by John Worall and Gregory Currie. Cambridge: Cambridge University Press.

Martens, Kerstin and Anja P. Jakobi (eds.) (2010) Mechanisms of OECD Governance - International Incentives for National Policy Making? Oxford: Oxford University Press. 
Martin, James (2008) 'Introduction' in The Poulantzas Reader. Marxism, Law and the State, edited by James Martin, London \& New York: Verso.

McNally, David (2009), "From Financial Crisis to World Slump: Accumulation, Financialization, and the Global Slowdown”” pp. 35-83 in Historical Materialism 17 (2009).

Miliband, Ralph (1983) “Poulantzas and the Capitalist State”, New Left Review 82, 1983.

Morton, Adam David (2007) Unravelling Gramsci. Hegemony and Passive Revolution in the global economy, London: Pluto Press.

Murphy, Craig N. (1994) International Organization and Industrial Change. Global Governance since 1850, Cambridge: Polity Press

Ougaard, Morten (1988) "Dimensions of Hegemony”, Cooperation and Conflict Vol. XXIII pp. 6479.

Ougaard, Morten (1990) Magt og interesser i den globale samfundsformation, Aarhus University Press.

Ougaard, Morten (2002) “Global polity research: Characteristics and challenges” 23-39 in Towards a Global Polity edited by Morten Ougaard and Richard Higgott, London: Routledge.

Ougaard, Morten (2004) Political Globalization, Palgrave.

Ougaard, Morten (2006) “Instituting the Power to Do Good?” 227-247 in Global Corporate Power. International Political Economy Yearbook Vol.15 edited by Christopher May, New York: Lynne Rienner Publishers.

Ougaard, Morten (2010) “The OECD’s Global Role: Agenda Setting and Policy Diffusion” 26-49 in Mechanisms of OECD Governance - International Incentives for National Policy Making? Edited by Kerstin Martens \& Anja P. Jakobi, Oxford: Oxford University Press.

Ougaard, Morten (2011a) Nicos Poulantzas, København: Jurist- og Økonomforbundets forlag.

Ougaard, Morten (2011b) "A new Role for the OECD? The 'Enhanced Engagement' strategy toward emerging economies” 91-109 in Governing the Global Economy, Edited by Dag Harald Claes and Carl-Henrik Knutsen, Routledge.

Panitch, Leo and Sam Gindin (2010) "Capitalist crisis and the crisis this time”, 1-20 in Socialist Register 2011.

Poulantzas, Nicos $(1973,1978,1981)$. (PPSC) Political Power and Social Classes, London: New Left Books 1973, Verso 1978, 1981. French Original 1968.

Poulantzas, Nicos $(1974,1979)$ (FD) Fascism and Dictatorship. The Third International and the Problem of Fascism, London: Verso Editions. French original in 1970, revised 1974.

Poulantzas, Nicos (1975) (CD) La crise des dictatures. Portugal, Grece, Espagne, Paris: Maspero. Danish translation: Diktaturernes krise, København: Aurora.

Poulantzas, Nicos (1976) 'The Capitalist State: A Reply to Miliband and Laclau', New Left Review no. 95, reprinted in Martin 2008.

Poulantzas, Nicos (1978) (CCC) Classes in Contemporary Capitalism, London: Verso.

Poulantzas, Nicos (1979) “The political crisis and the crisis of the state”373-393 in J.W. Freiburg (ed) Critical Sociology: European Perspectives, New York 1979, reprinted 294- 322 in Martin 2008, French original 1976.

Poulantzas, Nicos (1980, 2000) (SPS) State, Power, Socialism, London: Verso.

Robinson, William I. (2002) 'Capitalist globalization and the transnationalization of the state' 210-229 in Historical Materialism and Gobalization edited by Mark Rupert and Hazel Smith, London and New York: Routledge.

Rupert, Mark (2003) "Globalising common sense: a Marxian-Gramscian (re)-vision of the politics of governance/resistance” 181-198 in Review of International Studies 29.

Scholte, Jan Aart (ed.) (2011) Building Global Democracy? Civil Society and Accountable Global Governance, Cambridge: Cambridge University Press. 
Shaw, Martin (2000). Theory of the Global State. Globality as an Unfinished Revolution, Cambridge: Cambridge University Press.

Slaughter, Anne-Marie (2004) A New World Order. Princeton and Oxford: Princeton University Press.

Teschke, Benno (2011) “The Fetisch of Geopolitics. Reply to Gopal Balakrishnan” in New Left Review no. 69.

Trondal, Jarle, Martin Marcussen, Torbjörn Larsson, Frode Veggeland (2012) Unpacking international organisations. The dynamics of compound bureaucracies, Manchester and New York: Manchester University Press.

Tsingou, Eleni (2010) "Transnational Governance Networks in the regulation of finance", 138-155 in Business and Global Governance, edited by Morten Ougaard and Anna Leander, London: Routledge.

Vormedal, Irja (2012) "States and Markets in global environmental governance", 251-275 in European Journal of International Relations, vol. 18 no. 2.

Wight, Colin (2006) Agents, Structures and International Relations. Politics as Ontology, Cambridge: Cambridge University Press. 